\section{A CASE IN WHICH AN ARTIFICAL TOOTH WAS DISLODGED, SWALLOWED, AND IMPACTED IN THE CESOPHAGUS;}

\author{
SUCCESSFULLY EXTRACTED.
}

\section{BX JOHN DEARDEN, M.R.C.S.E.}

IT may not be uninteresting to some of the readers of The Lancex to peruse the following notes.

Mr. $\Psi_{-}$, aged thirty, presented himself at my surgery at noon of the 30th of August, 1869, and stated that, on taking a glass of water to drink, a front false tooth with the gold plate had become dislodged, and that he had swallowed it. He appeared to be much distressed, and complained of great pain in the epigastric region. I asked him to drink a little water; after doing which he complained of great pain and diffeulty in swallowing about the spot above described. I proceeded to pass a probang, measuring fourteen inches; about eleven inches of which passed readily enough, when it came against some hard resisting body, which I took for granted was the tooth. I immediately tried to force it down, but to no avail. Having no forceps long enough, I at once fixed on the probang about twenty nooses of strong horsehair, the nooses lying upwards, as will be seen by the engraring. I passed it down, and with much difficulty succeeded in getting it past the obstacle. I then mado gentle traction; and manipulating until I found that some of the nooses had become fixed, I then increased the force, but found the resistance so great that it seemed impossible either to bring up the probang or the tooth. At last the horsehair gave way, and the probang came up, leaving the tooth in the same place. I repeated the operation several times with little better success, the horsehair being most often cut through; once the tooth was drawn as high as the cricoid cartilage. I resolved upon trying fresh material for the nooses, and having some very fine steel wire, which I use for sutures, with this I armed the probang, and proceeded to pass it, only more readily than before. After a little careful management and considerable force, to the intense relief of the patient, I succeeded in extracting the tooth. The time occupied from first to last was about forty minutes.

Sept. 8th.-With the exception of soreness for the first few days after the operation, and restricting himself to a farinaceous diet, the patient has felt no inconvenience, and is now perfectly well.

Fra. 1.

FIG。2.
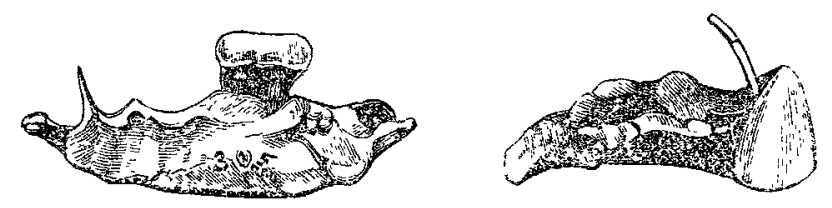

Fig. 3.

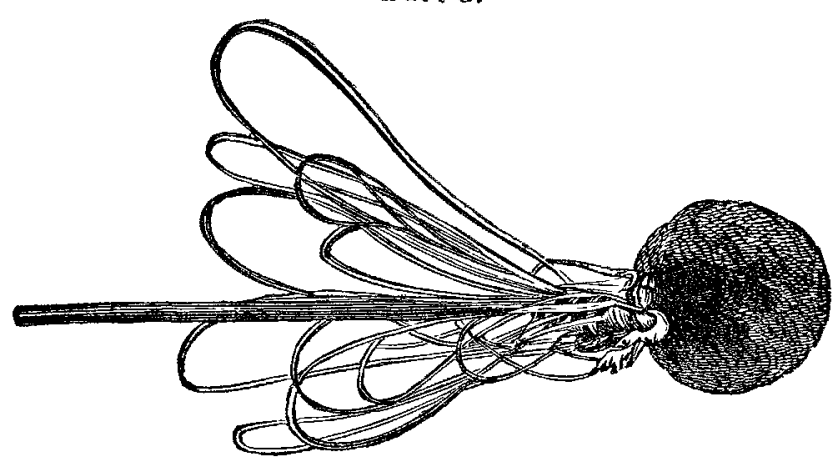

Figs. 1 and 2 are accurate representations of the artificial tooth and plate. The measurement from point to point is

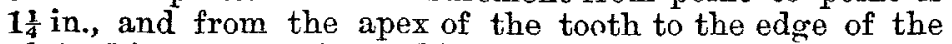
plate $\frac{5}{8}$ in. The spike, which is noticeable on Fig. 2, is $\frac{5}{16}$ in. in length; it use was to secure the tooth more firmly by being received into a hole drilled into the old stump.
I need scarcely make any remarks about the difficulty of extraction when the number of points and the very irregular outline of the plate are taken into consideration.

Fig. 3 represents the probang armed with the nooses. Brook House, Church, near Acerington, Sept. 1869.

\section{a a thitror}

OF THE PRACTICE OF

\section{MEDICINE AND SURGERY}

\author{
IN THE
}

\section{HOSPITALS OF LONDON.}

Nulla autem est alia pro certo noscendi via, nisi quamplurimas et morborum et dissectionum historias, tum aliorum, tum proprias collectas habere, et inter se comparare.-Morgagni De Sed. et Caus. MIorb., lib. iv. Procmium.

\section{ST. GEORGE'S HOSPITAL.}

\section{CASES OF PHAGED ENA.}

So much has been written lately about the healthiness of the large London hospitals, that it may be worth while to relate the following five cases of phagedrena, admitted into St. George's Hospital, as bearing upon the question. Mr. W. Leigh, the surgical registrar, has obliged us with the notes. Up to the present time, these cases are the only ones of the kind that have come under notice at that hospital this year. They have all occurred since the latter end of June; and, as will be seen, they came from various localities-three from the crowded districts of Chelsea and Pimlico, and the other two from a bealthy part of Kensington and from Hampton respectively. In only one case did the sloughing continue for a longer period than two days after the patient's admission; and though all, with the exception of the last case (which was placed in a separate room), were placed in wards containing patients with various kinds of wounds, in no instance was any wound in the hospital attacked with phagedæna. In Case 3 the slonghing certainly had ceased before the patient was admitted, and therefore there might be less chance of its spreading and attacking neighbouring wounds; still it shows that even the country village of Hampton is not free from phagedæna. The treatment consisted in supporting and even stimulating the patients, wi'h the free administration of opium. Locally, poultices with a stimulating ointment were applied till the wound took on a healthy form.

CAsE 1.- Harriet B-, aged twenty-two, married, living at Westbourne-street, Pimlico, was admitted into Wellington ward on June $29 \mathrm{th}$, under the care of Mr. Holmes. The history she gave was that two years ago she had fever, and had always been delicate since. Twelve months ago she knocked off the skin from her right leg, which had never healed. For two weeks it had been inflamed, very painful, and rapidly increasing in size. On admission she was pale and in a weak state. There was a large sloughy ulcer, about four inches in diameter, on the outer side of the right leg; the skin around was much inflamed; the edges of the ulcer were sharp and everted. She was ordered ordinary diet; a pint of porter and three ounces of port wine daily ; tincture of opium, ten minims, with fifteen grains of chlorate of potash; quinine and iron. Two days after admission the edges of the ulcer were healthy and the slough separating. She was discharged from the hospital July 17 th, with a healthy ulcer almost healed.

CASE 2.-John J-, aged thirty, a labourer living at Earl's-court, Kensington, was admitted into Grosvenor ward June 30th, under the care of Mr. Hewett. Ten years ago his left leg got wounded by a stone rolling against it, and had been ulcerated at times ever since. Ten days before admission it became very painful, and got rapidly larger. On admission, there was a large phagedænic ulcer, the size of a man's hand, on the inner side of the left leg; very painful; edges everted and spreading. He was ordered ordinary diet; one pint of soup and one pint of porter; tincture of opium fifteen minims, chinchona draught, thrice daily: On July 2nd the slough had not spread, and the 